\title{
WAQF FUNDRAISING MANAGEMENT: A PROPOSAL FOR A SUSTAINABLE FINANCE OF THE WAQF INSTITUTIONS
}

\author{
Muhammad Shulthoni ${ }^{1}$ \\ Norma Md Saad ${ }^{2}$ \\ Saim Kayadibi ${ }^{3}$ \\ Muhammad Irwan Ariffin ${ }^{4}$
}

\begin{abstract}
This paper studies the theoretical structure of financing for Islamic philanthropy in the form of waqf or endowment by looking at the past and present forms of waqf. Waqf is expected to play a more important role to tackle current social and educational issues, where financial sustainability has become one of the greatest challenges faced by waqf institutions. Using the content and thematic analysis approaches, this paper reviews the practice of successful waqf institutions and summarizes the features that are significant to a successful waqf fundraising and management. The paper analyzes three models that are suitable for innovation and management of waqf fundraising: Venture Philanthropy of Waqf Model (VPWM), Value-Based Capital Model of Waqf (VBCM), and Social Enterprise Waqf Fund Model (SEWF). The paper then investigates the possibility of applying the Management by Objectives (MBO) framework to improve the overall management of waqf institutions. The discussions are hoped to be able to contribute towards developing a better fundraising and management of waqf institutions.
\end{abstract}

Keywords: Waqf Fundraising, Management, Financing Models, Waqf Institutions. JEL Classification: G23, L31, O35, Z12

Received : September 17, 2017

Revised : April 20, 2018

Accepted : May 12, 2018

1 Ph.D candidate at International Islamic University Malaysia (IIUM) and a lecturer at the Islamic Economics Undergraduate Program, Faculty of Islamic Economics and Business, Institut Agama Islam Negeri (IAIN) Pekalongan, Central Java, Indonesia, Corresponding author: muhshulthoni@gmail.com.

2 Professor, International Islamic University Malaysia, Malaysia, Email: norma@iium. edu.my

3 Associate professor, International Islamic University Malaysia, Email: saim@iium. edu.my

4 Lecturer, International Islamic University Malaysia, Malaysia, Email: irwan@iium. edu.my 


\section{INTRODUCTION}

Waqf plays a pivotal role in providing social benefits in Muslim societies. It has developed progressively since its beginnings and has benefited Muslims by financing public expenses. It is considered one of the oldest charitable foundations in the world, traced back to Prophet Ibrahim (peace be upon him), who devoted his property in acts of charity, including the construction of the Ka'bah (McChesney, 1995; Kahf, 2000; Zakaria, Samad, and Shafii, 2012; Stibbard et al., 2012).

Waqf has also been one of the economic pillars of Islam since the time of Prophet Muhammad (blessings and peace be upon him), having catalyzed economic development among Muslims (Tahir and Brimble, 2011). Despite there being no specific reference to waqf in the Qur'ān (Kuran, 2001), this institution is a tool developed by Muslims to support many essential needs that are today financed by the government, such as schools, hospitals, orphanages, graveyards, mosques, religious foundations, and other essential infrastructural facilities (Mahamood, 2006). Finally, this institution, according to Cizacka (2011), is one of the redistribution of wealth institutions, and its objective is not for the sake of profit but to support the general good and the well-being of the whole society while seeking reward (thawāb) with Allah (Almighty) in the Hereafter.

The evolution of waqf has gone through substantial progression, stagnation, and even regression (Cizacka, 2000; Siraj, 2012). The colonization of Muslim nations after the Second World War greatly undermined the importance of the waqf system in Muslim societies. The stagnation of the waqf system was much more pertinent during the $19^{\text {th }}$ and $20^{\text {th }}$ centuries, as modern Western states became more powerful and less tolerant of opposing organizations, including waqf (Stibbard and Bromley, 2012). However, historically, waqf has considerably contributed to human civilization in Muslim societies, above and beyond ordinary charity (Hoexter, 1998).

According to Mahamood et al. (2015), waqf is considered as a pious donation and is related to the religious awareness on charity. In short, its contribution is remarkable in solidifying religious practices, developing knowledge, improving education, as well as a diffusing culture within Muslim societies (Siraj, 2012; Mahamood and Rahman, 2015). In other words, waqf had significantly contributed to the well-being and educational development of the Muslim societies. It was a successful and exemplary model for funding and sustaining Islamic educational institutions, such as universities, schools, madrasahs and other public services in the past that some of these institutions are still in existence. ${ }^{5}$

Nowadays, however, the Muslim societies expect that many awqāf institutions should take over more responsibilities to meet the current social and educational problems. There are challenges to be faced by significant numbers of awqāf institutions today. These challenges remain on how to mobilize and manage their resources to improve Islamic educational institutions, societal economic development and help preserve the vast liquid assets from being lost in the neverending circles of charity. There are evidences that suggest that considerable figures of waqf assets and awqā $f$ institutions are mismanaged and many suffered from lacked funds to generate productive use of waqf assets (Hasan and Shahid, 2010).

5 The waqf-based Islamic educational institutions, for example, are Al-Azhar University in Egypt and Al-Zaytuna University in Tunis. 


\section{LITERATURE REVIEW}

As a subject matter, fundraising and its correlated issues, such as supply and demand of donation, marketing, management and performance, has not gained much attention on waqf literature. The lack of published empirical research regarding waqf fundraising is possibly because the theme of waqf is neglected and only involved a few academics, students and researchers (Lindhl, 2002 and 2011; Mahamood and Asmak, 2015).

Furthermore, previous studies on waqf are merely concentrating on several themes such as financing (Ahmed, 2007; Mahamood, 2007; Hasan and Abdullah, 2008; Ahmed 2009), Islamic insurance (Hashim, 2007), and innovation of economic models of waqf (Mahamood, 2006; Jalil and Ramli 2010), the legal aspects of waqf and its broader implications within the economy (Hoaxter, 1997), education (Gaudiosi, 1987), and the social system and the state (Hoexter, 1997). There are only a few researches work that focus on the performance of waqf management (Sulaiman et al., 2009) and the accountability of waqf management (Ibrahim and Yaakob, 2006; Ihsan and Ibrahim, 2011; Nahar and Yakoob, 2011; Siraj, 2012; Ihsan, 2014).

It can be argued that the studies of waqf, in general, are center on the legal, historical and administrative perspectives. There are a few important works which illuminate the waqf management investments, assets enhancement programs and income generating activities. However, these discussions are limited to the role of waqf in financial institutions. For example, Kahf (2000) attempts to provide new techniques for financing the development of waqf properties, especially the investment waqf for providing financial needs which are compatible with shari'ah. In addition, Daud (1999) points out that developing waqf property needs a combination of the elements of fixed savings and investment for the production of future benefits.

Several previous studies revealed that the development, unstructured management of waqf institutions (Prihatna, 2005), funding, technical expertise, inefficiency, and ineffectiveness (Al-Habshi, 1991) are some examples of the awvqāf problems that need to be solved. Mohammad (2008) identifies that insufficient legal provisions, poor information system, lack of trained employees, lack of trust and insufficient financial resources are the major constraints in developing waqf properties. Other problems pointed by researchers in relation to management of awqāf are lack of accessibility, unskilled nāzirs (Hasanah, 2003), misuse of waqf assets (Al-Makassary, 2003), doctrinal understanding of waqf (perpetuity and inalienability), and special purpose of waqf (Harasani, 2015). Furthermore, Mohammad and Iman (2006) observe that the three basic components which form the basis of creation of waqf, specifically irrevocability, perpetuity, and inalienability have become the components that presented undesirable effects on realizing full benefits from waqf, such as problems of liquidity and cash flow, ensuing in legal conflict particularly for contemporary waqf (i.e. cash waqf). As a result, there is limited cash flow that subsequently blocked the growth of waqf.

This is an indication that the present circumstances of most awqāf institutions are unsatisfactory. The role of nāzirs has come into mistrust. It can be said that in many areas there has been a catastrophic downfall of awqāf. The awqāf institutions are not given the right maintenance and therefore, enormous awq $\bar{a} f$ assets are ill- 
managed. In addition, according to Hasan and Shahid (2010), the unavoidable consequence is much deterioration and disrepair of these valuable assets. Regarding this issue, there is a contention that the decentralization (privatization) of waqf is a fit structure of waqf management, since its centralization (nationalization) led to mismanagement of waqf and opened the door to many problems in a lot of Muslim countries (Sait and Lim, 2006). For example, it triggered unemployment, as the nāzirs who were selected by the wāqif became reliant on monthly wages, without administering the waqf assets properly. In addition, Baskan (2002) emphasizes that there is a necessity in returning the waqf assets to private organization by establishing waqf boards of trustees independent of the government ministry. It can be argued that the transferring of waqf management to the independent body will bring benefit as waqf assets is managed in a professional manner.

From the stated situation of the awqā $f$ institutions in many Muslim countries, considerable efforts have to be made in the progressive way in order to find the proper approach to maintain the existing waqf assets and funds. Undeniably, the current reassessment of the role of the waqf supports anticipations to study from the faults of the past and to move for managing the waqf assets and funds in a professional manner within modern management framework.

To revive these awqāf institutions, there is a need to study various models of fundraising that could be applied in the awqā $f$ institutions. Therefore, this paper aims to identify and analyze several fundraising models, management, and innovation in the development of waqf assets and funds in the Muslims' World.

\section{METHODOLOGY}

This paper is a literature review. It employs an explanatory approach, which relies on the interpretation and understanding of the researcher. Data is collected from several sources, such as observation and review of documents. This helps triangulate the data and then apprehend the substance of waqf fundraising management. The findings will be analyzed using content and thematic analysis approaches. These approaches are expected to facilitate identification of significant features of large data and answer the set of questions.

\section{IV.RESULT AND ANALYSIS}

\subsection{Definition of Waqf}

The Arabic term waqf (plural awqāf) means the act of creating a religious endowment. Waqf, tahbis and tasbill are the explicit words for the waqf (Abbasi, 2012). Sadaqah, ta'bld and tahrim are its implicit expressions (Sabri, 2008; Abbasi, 2012). It is an Arabic mașdar (root) meaning "to prevent, restrain" (Sabri, 2008). Additionally, the etymological meaning of waqf is "stop, block, and suspend" (Jones, 2005). According to Kahf (1999) and Raissouni (2001) which is cited by Hasan (2010), the literal meaning ${ }^{6}$ of waqf is forbidding movement, transfer, or exchange; it is a devoted asset usufruct of which is to be used for a number of giving ends for the extent of the property's presence.

6. According to Ibn Manzur (Lisān Al- 'Arab, 1994, vol. 15), waqf is forbidding movement. It cannot be sold nor inherited. 
In Islamic epistemology, the meaning of waqf was understood differently by classical jurists of the various Islamic schools of law.7 According to the Hanafi school of law, a waqf is "the detention of corpus from the ownership of any person and the gift of its income or usufruct either presently or in future to some charitable purpose" (Cattan, 1955; Mahamood, 2006; Stibbard et. al, 2012). In addition, AlSarakhsī (1993, vol. 12) describes waqf as primarily "to protect a thing, to prevent it from becoming the property of the third person (tamlik)" (p. 27). It can be inferred that Imām Abū Hanifah based his concept on the hadith narrated by Ibn Umar (may Allah be pleased with him), "If you want, make the land itself unalienable and give [the yield] away as alms (in shi'ta habbasta așlahā wa tașaddaqta bih $\bar{a}^{8}$ )" (Gil, 1998, p.126). Imām Abū Hanīfah, however, perceives that the ownership of the corpus continues on the authority of the founder (wāqif), while its return (usufruct) is dedicated to beneficiaries (Abbasi, 2012). In addition, Al-Khatib (1968, p. 44) highlights that the founder of waqf, according to this view, remains the owner, but loses the rights of selling, bequeathing, or giving away the dedicated property. Accordingly, Imām Abū Hanīfah believes that waqf is considered like 'áriyah' which can be revoked, and for that reason, it should have all its characteristics (AlSarakhsī, 1993, vol. 12, p. 27; Al-Marghinani, 1997).

His (Imām Abū Hanīfah) disciples such as Abū Yūsuf and Muhammad AlShaybān̄̄ as well as jurists of other madhāhibs, however, do not adopt Imām Abū Hanīfah's definition. As was stated by Abū Yūsuf and Al-Shaybān̄i, waqf is "the tying up of the substance of a thing ('ain) under the rule of the property of Almighty Allah so that the proprietary right of the waqf becomes extinguished and is transferred to Almighty Allah for any purpose by which its profits may be applied to the benefits of His creatures" (Ali, 1912, p. 336). Additionally, according to this view, the founder's right of ownership ends; it is usually said that it passes to Allah.

The Māliki jurist Ibn 'Arafa defines waqf as "the grant of usufruct of a thing that is binding on the founder for duration of its existence; the ownership remains hypothetically with the founder, although he is no longer entitled to use the substance of the property" (Al-Hattab, 1911, p. 18; Layish, 1983, p. 3; Powers, 1993, p. 1173). According to this opinion, the owner still holds the property, without the right to use its substance. In other words, the founder is banned from exercising it.

Al-Shāfi'i scholars define waqf as "the alienation of revenue generating property by the founder, with the principle remaining inalienable, while its revenues are disbursed for a pious principal in order to seek God's favour" (Al-Nawawi, 1985, p. 314). At

7. The four Sunni schools of law still in existence are the Hanafi, the Māliki, the AlShāfi'i, and the Hanbali schools. These schools of jurisprudence are identified in Islam as madhhab or madhhāhibs. They do not constitute separated legal system rather represent together as one integral system within the Sharī'ah (Badr, 1978). The schools of law are found to be dominant in certain geographical areas and sometimes having different interpretations towards aspects of waqf. Accordingly, the practice of waqf varies between regions depending on the prevailing Islamic school of law (madhhab). 8. Al-Bukhāri, 1996, vol. 2, p. 96.

9. 'A riyah is temporary borrowing for limited time where the possession of the thing is given for use only while the ownership is retained by the original owner (Abbasi, 2012; see also Al-Quduri, 1997, p. 133). 
this point, Al-Nawawi (1978) opines that the purpose of the bequest must be an "act of beneficence" (birr) and a "good work" as a means of "approach to Allah (Almighty)" (taqarrub), even though this is not constantly visible in practice. Meanwhile, Hanbali jurists describe waqf as "tying up of the substance of a property and the devoting of its usufruct for the benefit of mankind, in such a manner that ownership of it belongs to Allah (Almighty)" (Anderson, 1951; Mahamood, 2006). From the definitions, it can be inferred that Al-Shāfi'is and Hanbalis are in opposition to the view that the waqf remains the property of the founder and his inheritors. Referring to this view, some Al-Shāfi'i jurists, on the one hand, argue that the right passes to Allah, and on the other, they believe that the ownership passes to beneficiaries.

In the modern context, Othman (1983) opines that waqf has the following meaning: "...estates fall under a perpetual trust and they cannot be sold, exchanged or dealt with any manner that conflicts with the purpose for which they were originally constituted". In other words, waqf may be designated as a provision of valuable assets that is devoted to a legitimate institution to generate benefits for the needy. Here, the term 'valuable assets' covers both of moveable and immovable assets. It is not limited to specified assets that can be utilized as waqf [assets] as long as they have future economic benefits.

Kahf (1998) defines waqf as "holding māl (an asset) and preventing its consumption for the purpose of repeatedly extracting its usufruct for the benefit of an objective representing righteousness and philanthropy" (p.4). ${ }^{10}$ This definition highlights the notion of abstention from consumption with the purpose of preserving the asset for continued use of the usufruct. It covers the family waqf which gives the possibility of utilizing the waqf by the founder. Additionally, Kahf (1999) defines waqf for stating the economic content as "diverting funds and other resources from consumption and investing them in productive assets that provide either usufruct or revenues for future consumption by individuals or groups of individuals" (p. 42). Waqf here is a combination of the acts of saving and investment simultaneously. In other words, it is abstaining from current consumption to increase the future output of services and income from a productive asset. The waqf may produce output to be distributed to the community in order to generate revenue for the beneficiaries of the waqf.

To conclude, despite various terminologies and epistemologies having been described by traditional and modern jurists, it can be argued that the essential practical meaning of waqf is agreed as "the devotion of wealth either in stated terms or by implication, for any charitable or religious purpose, or to protect any benefit to human beings" (Mahamood, 2006; Abu Zahrah, 2007; Siraj, 2012). In other words, the description of the spirit of waqf is similar in all the madhāhibs with slightly different interpretation of the essentials of waqf.

\subsection{The Basic Concept of Fundraising}

Non-profit and non-governmental organizations need resources to attain organizational goals and realize their missions as well as to proceed and develop their activities (Cacija, 2013). Andreasen and Kotler (2008) point out that the

10. See also Kahf (2000). 
essential resources needed for non-profit organizations are financial and human resources. Financial resources include revenues from sales of products and services, whereas human resources consist of employees and volunteers. In other words, it can be said that the success in raising funds and managing human resources are critical to the performance of non-profit organizations.

A non-profit organisation is pervasive, and its organization is multifaceted. Different terms are used to refer to the sector. According to Worth (2009, pp. 9-10), the terms "non-profit, independent sector, third sector, charitable sector, voluntary sector, tax-exempt sector, and social enterprise" are used interchangeably to define the sector. 'Philanthropy', 'giving', 'social economy' and sometimes 'civil society' are other names for this sector (Salamon and Anheier, 2006). However, the agreement on using a single term has not been reached, as such the general description of the non-profit organization and non-profit sector is commonly used interchangeably. According to Masyita (2012), in common law countries, non-profit organisations commonly consist of three organizational forms: associations, trusts and charitable or non-profit corporations. In civil law countries, according to Ahmed (2007), there are two organizational practices of non-profit organisations, associations and foundations; although in some countries the practise of limited liability companies exists.

Before proceeding further, a clear understanding of structural positioning of the waqf institution within the non-profit organizations is required. One may prefer to categorize waqf as the third sector organization or voluntary sector. Arshad and Haneef (2015) point out that since the waqf institution contributes to public and social services in the Muslim community with the absence of market or state agencies, being considered a third sector is suitable. The following figure describes a matrix of four types of non-profit organizations based on the source of income, namely donative mutual, donative entrepreneurial, commercial mutual and commercial entrepreneurial.

Table 1. Organizational Style Based on the Source of Income

\begin{tabular}{ccc}
\hline Source of Income & Mutual & Entrepreneurial \\
\hline Donative & Donative Mutual & Donative Entrepreneurial \\
\hline Commercial & Commercial Mutual & Commercial Entrepreneurial \\
\hline
\end{tabular}

Source: Hansmann (1980).

The Table 1 demonstrates some typical examples of these four types of organization. It can be argued that the intersection of the previous divisions in terms of finance (source of income) and management constructs four categories of nonprofits: (1) donative mutual; (2) donative entrepreneurial; (3) commercial mutual; and (4) commercial entrepreneurship. The flexibility of the foundation statutes tolerates non-profit organisations to assume a wide variety of forms. According to Hansmann (1980), the category of each non-profit organization depends on its source of income and the way in which it is organised. Using Hansmann's (1980) classifications, waqf institutions as one of the non-profit organizations that receive most of its income in the form of donations can be categorised as "donative" non- 
profits. Furthermore, waqf as a non-profit institution that is fundamentally free from the exercise of formal control by its patrons can be termed as "entrepreneurial" non-profits. Consequently, donative and entrepreneurial non-profits should be considered the ideal types for waqf institutions.

Since waqf institutions share some characteristics with non-profit organisations, fundraising is an essential element for the running of these institutions. Functioning, suitable, and effective fundraising methods are required to secure the preferred human and financial resources. Although waqf in some categories is common around the Muslim world, organized fundraising and waqf on a huge scale is still mostly an extraordinary phenomenon for the Muslim community. Lindahl and Conley (2002) argue that "little study focuses on fundraising for religious institutions, although it is a fact that this category constantly attracts the huge amount of charitable funding each year" (p. 91). Additionally, it is necessary to recognize the concept of fundraising comprehensively in the waqf institution in order to boost its development. This is because of the significance of waqf as one of the most vital non-profit organizations that exist in the Islamic legacy.

Although the term 'fundraising' can be largely defined to take into account political fundraising and raising funds for business ventures, this research focuses on the efforts engaged in raising a provision for non-profit charitable organization, namely waqf. Fundraising is sometimes understood as tantamount with non-profit organisations (Worth, 2009). The term fundraising is frequently used interchangeably with the term 'development or advancement'.

According to Worth (1993), fundraising is a movement that started with the goal of producing charitable or philanthropic giving. In the simplest words, fundraising means "asking for a gift" even though it is a long process in which asking for a gift. In other words, it is a step in more complicated processes (Worth, 2009). Andreasen and Kotler (2008) describe fundraising as an activity of accumulating financial resources and ascertaining the fundamental bases of funds. Also, Warwick (1999) highlights that fundraising is not only an effort to procure funds for the organization, but also includes the creation of a donor base, making donors active, visible and efficient.

From the definitions given above, it can be inferred that fundraising, as the movement focused on obtaining monetary and non-monetary resources from benefactors, is hard to be explained. Some prefer to emphasize on the collection of funds, while others concentrate on the fundraising activities and tools. According to Holloway (2001), fundraising can be classified into three formulas: (1) raising moveable and immovable resources from the society; (2) creating a base of revenues from the existing assets by investment and innovation; and (3) utilising non-monetary resources such as volunteers, equipment, and positive images of the institutions to achieve the resources. In short, this research adopts Holloway's categorization of fundraising.

Hence, it can be argued that fundraising in waqf institutions covers all efforts to provide financial and non-financial resources in an attempt to integrate it into social entrepreneurial activities. However, these initiatives require a general model for the development of waqf fundraising and management. The operation of these initiatives will be discussed comprehensively in section 4.4 (Proposed Methods of Fundraising). 


\subsection{The Significance of Fundraising}

In the context of non-profit organisations, fundraising has focused on the donor's preference in its expansion, and subsequently, it cannot be viewed as only a demand for cash based on the charitable purposes, but reasonably as the interchange of values which meet the benefactors' need (Andreasen and Kotler, 2008; Cacija, 2013). Whereas in waqf institutions, a larger number of them do not share such an orientation to fundraising, as most of them are deliberating on sustaining organizational necessities.

However, according to Cacija (2013), fundraising becomes "a strategic approach to benefactors and establishment of long period relationships which may not primarily produce planned returns in a short time" (p. 60). It can be agreed that fundraising is one of the main activities of non-profit organizations and an important factor to develop organizational performance. In addition, there is a need to create an integrated fundraising model that includes both non-profit marketing activities ${ }^{11}$ and elements of the non-profit marketing management: planning, implementation, analysis, and control (Cacija, 2013).

In this respect, it is interesting to note that there are basic principles of fundraising in the framework of waqf. Firstly, the Muslim communities are the base of the entire waqf fundraising process, since a wäqif designates to provide financial or non-financial provision to nāzir in order to help other Muslims (beneficiaries) (Kahf, 2000). In this manner, the significance of a minor endowment should not be weakened, as a wāqif gives endowment obviously in coherence with his available assets.

Secondly, religious leaders, waqf administrators, and volunteers have to display devotion to their waqf institution by voluntarily working to persuade the prospective wāqif and to guarantee the realization of the objectives and warrant their endowments (Lindhl, 2011). This basis indicates that the relationship between the wāqif and nāzir in the perspective of marketing is essential theoretically for fundraising performance that may impact on the success of the waqf institutions.

Lastly, Karim (2012) highlights the significance of fundraising and marketing in order to expand the base of waqf assets into several initiatives: (1) Creating a cash waqf fund through fund management; (2) Expanding the existing waqf assets through istibdāl and developing their parties; and (3) Marketing the waqf overseas to reach out to global philanthropists. Subsequently, these initiatives could be implemented to speed up the development of waqf assets in order to meet the growing demands of the community.

11. According to Coviello and Brodie (1998) there are two models of marketing: relationship approach and transactional approach. In the practices, they argue that the relationship marketing approach is better than its counterpart. Moreover, Gronroos (1996) points out that traditional approach (the marketing mix, the marketing department, marketing planning, marketing segmentation, and performance measurement based on market research and market share statistics) is no longer appropriate for contemporary marketing practice. 


\subsection{Proposed Methods of Fundraising}

Having discussed that fundraising is an important part of the functioning of any non-profit organization, using the right and effective fundraising methods and techniques is necessary to guarantee that the needed financial support is achieved and maintained (Tedham, 2012). For waqf institutions, fundraising can be understood as a kind of activity and an opportunity to maximize social benefit and financial return. It is a significant factor when considering the fundraising strategies to ensure the financial and social impact sustainability of the waqf.

Regarding waqf, there are challenges for waqf institutions in modern time. There is a common acknowledgement that many awqāf institutions have stagnated and are not performing their designated social functions (Stibbard et al., 2012). The waqf institutions are forced to compete directly or indirectly for wāqif, volunteers, nāzirs, and for the time and resources of supporters (Siswantoro and Dewi, 2007). Therefore, nāzirs have to innovate fundraising by constructing new techniques to generate additional and numerous sources of income. In other words, they have to run entrepreneurial strategies in generating fund and organizing human resources. Furthermore, according to Sargeant (2001), there are two methods to generate revenue or raise funds: (1) the 'transactional approach' which focuses on the instant financial needs of an organisation without attaching in the developing a strategic plan; and (2) the 'strategic approach' that is based on the organisation's long-term design which should benefit from the collaboration of multiple fundraising schemes and activities.

Hasan and Shahid (2010) point out that there is a belief that waqf institution could play a greater role in the progression of social and economic development with education, health care, social welfare and other community-based programs. In order to reach this step, there is a need to pay attention to the development of the existing waqf assets to revitalize their purpose and capability to deliver these essential services in the present and the future. One of the biggest problems related to revitalizing waqf, in many Muslim countries ${ }^{12}$, is the absence of funds for restoring the productivity of the properties as well as other moveable or immovable assets.

To overcome these problems, this study describes the innovation of various types of fundraising models with 'strategic approaches' that have been implemented relatively by the waqf-based pesantrens ${ }^{13}$ and can be used to finance the development of waqf in other awqäf institutions: (1) raising cash waqf fund through venture philanthropy of waqf model (VPWM); (2) preserving waqf properties by implementing value-based capital model of waqf (VBCM); and (3) initiating social enterprise waqf fund (SEWF) that offers an alternative investment.

12. For example, in Malaysia more than 13.000 hectare of idle waqf land, only $2 \%$ had been developed; In Indonesia there are more than 4 billion square meters registered waqf, only less than 1\% had been developed (Mohsen, et al., 2016).

13. Factually, Pesantren of Darussalam Gontor, Tazakka, and Darunnajah have been sustained by awqāffunds since the day were established. They have combined waqf and business to generate incomes in order to be less reliant on any sources of government funding (Wardun, 2015; Ahsanta, 2015; Buletin Darunnajah, 2015). 


\subsubsection{Venture Philanthropy of Waqf Model (VPWM)}

One central problem in waqf management is how to proceed with the available waqf funds (especially cash waqf) so as to preserve its original value and to develop the value over time (Arshad and Haneef, 2015). In the context of cash waqf management, several models have been projected. There are many suggestions from practitioners and academics to expand the utilities of waqf into financing activities (Ahmed, 2007; Mahamood, 2007; Hasan and Abdullah, 2008) takāful (Islamic Insurance) and to develop inventive economic models (Mohammad, 2006; Jalil and Ramli 2010). Corporate waqf based on mushärakah and mudārabah models are widespread in the Muslim countries (i.e. Malaysia). In addition, Alias (2012) has suggested a model termed as the Enterprise Waqf Fund (EWF) to boost the function and the organization of cash waqf funds by engaging the venture capital or venture philanthropic systems and approaches. Finally, Zakaria, Samad, and Shafii (2013) proposed the VPWM in combination with the establishment of sustainable waqf businesses. They argue that a sustainable waqf business is able to ensure that the philanthropic activities will produce revenues consistently (Zakaria et al., 2013). In this phase, another form of the potential venture philanthropy models for cash waqf operations will be presented.

The concept of venture philanthropy is not a new concept for Islamic investments (Alias, 2012). This concept is based on the principles of venture capital, but in the Islamic (society) context, its purpose is to produce a financial and social benefit to the Muslim community. Conventionally, revenues from venture capital return to shareholders, while benefits from venture philanthropy endowments are reinvested in order to develop both its investment portfolio and development impact.

A number of philanthropists have defined venture philanthropy by emphasizing on different elements. So far, there is no single accepted definition of venture philanthropy. According to Pepin (2005), venture philanthropy seems to be similar to that of venture capitalists, taking the initiative, but investing in innovative ideas produced by donations. Alam (2010) highlights that venture philanthropy is not only a funding institution which is focusing on the financial resources but it is also engaging in the management and technical supports. This support is concentrated on empowering institutions to build better organizational capacity. One should keep in mind that the purpose of establishing a venture philanthropy or venture capital is to create a win-win solution between capital benefactor and the beneficiary (Zakaria, Samad, and Shafii, 2013). In other words, venture capital will possibly be focusing on financial returns on the investment while venture philanthropy would be expecting social benefits instead.

In 2006, Matthew Bishop in the Economist article publicized the term 'philanthrocapitalism' to illustrate a trend sweeping philanthropic institutions. There has been "a need for philanthropy to become more like the for-profit capital markets" (Bishop, 2006). In other words, according to McGoey (2012), the new idea of the philanthrocapitalism is "the explicitness of the self-interested motives underlying largescale charitable activities" (p. 197). Furthermore, Lorenzi and Hilton (2011) view that the term of philanthrocapitalism is as "the application by an individual of significant accumulations of financial capital to address social problems so as to affect social justice" (p. 398). It is dedicated to transfer the wealth -using business practices, tools, and 
market forces to develop the better social good-- from the rich to the poor. It can be inferred from the concept that there is a need to build social entrepreneur for philanthropists to invest in.

The building of social entrepreneur is designed as the application of human capital to produce social capital through the process of sustainable business practices (Lorenzi and Hilton, 2011). In some ways, according to Ramdas (2011), the philanthrocapitalism and venture philanthropy can be perceived as a normal expansion of the patterns of the capitalism as a reasonable alternative economic system.

Pepin (2005) explains venture philanthropy as one of the non-traditional charitable sources of revenues in the perspective of social entrepreneurship. He categorizes non-traditional source of returns into venture philanthropy, commercial ventures, and social venture capital (Pepin, 2005). The classifications share a similar characteristic which is to provide funding with the expectation to get returns that would be funded for social dedications (Zakaria et al., 2012). The returns are produced through commercial activities in order to gain the profits that will contribute to the sustainability. Indeed, in the capitalist system, there can be distinguished two types of business organizational entities.

On the one hand, corporations can be perceived as profit-maximizing business, whose objective is to produce shareholder value, and; on the other hands, nonprofit organizations exist to satisfy social objectives (Hull and Lio, 2006). The experience of Grameen, in the building social business of the microfinance, gives lot of lessons that can be learned. This social business, according to Yunus, et al. (2010), is projected and activated just like traditional business enterprise, with products, services, markets, expenses and revenues. Its concept is close to social entrepreneurships which includes both profit and not-for-profit initiatives (Yunus, et al., 2010).

In addition, it can be argued that a social business is an innovative practice of business that can be placed anywhere between a profit-maximizing and a nonprofit organization. It has difference with NGOs (non-governmental organizations) that most of which are not anticipating recovering their total costs from their operations (Werker and Ahmed, 2008). Thus, the NGOs are obliged to dedicate part of their time and energy to raising cash.

In line with Pepin (2005), Scarlata and Alemany (2010) use the term Philanthropic Venture Capital (PhVC) to define an investment that is not only focusing on maximising shareholders' prosperity but also on maximazing ethical dimensions of the social impact on the investments. ${ }^{14}$ Moreover, Scarlata and Alemany (2010) argue that the PhVC model is not only fund providers but also value-added services to portfolio organisations with the main objective of maximising the social impact or social return on the investment. Therefore, it can be agreed that adapting the model into waqf institutions would enable the development of waqf funds and assets in order to give more benefit to the beneficiaries. The modification of Scarlata and Alemany's (2010) model in waqf can be seen in the Figure 1.

14. See also Zakaria, Samad, and Shafii (2013). 


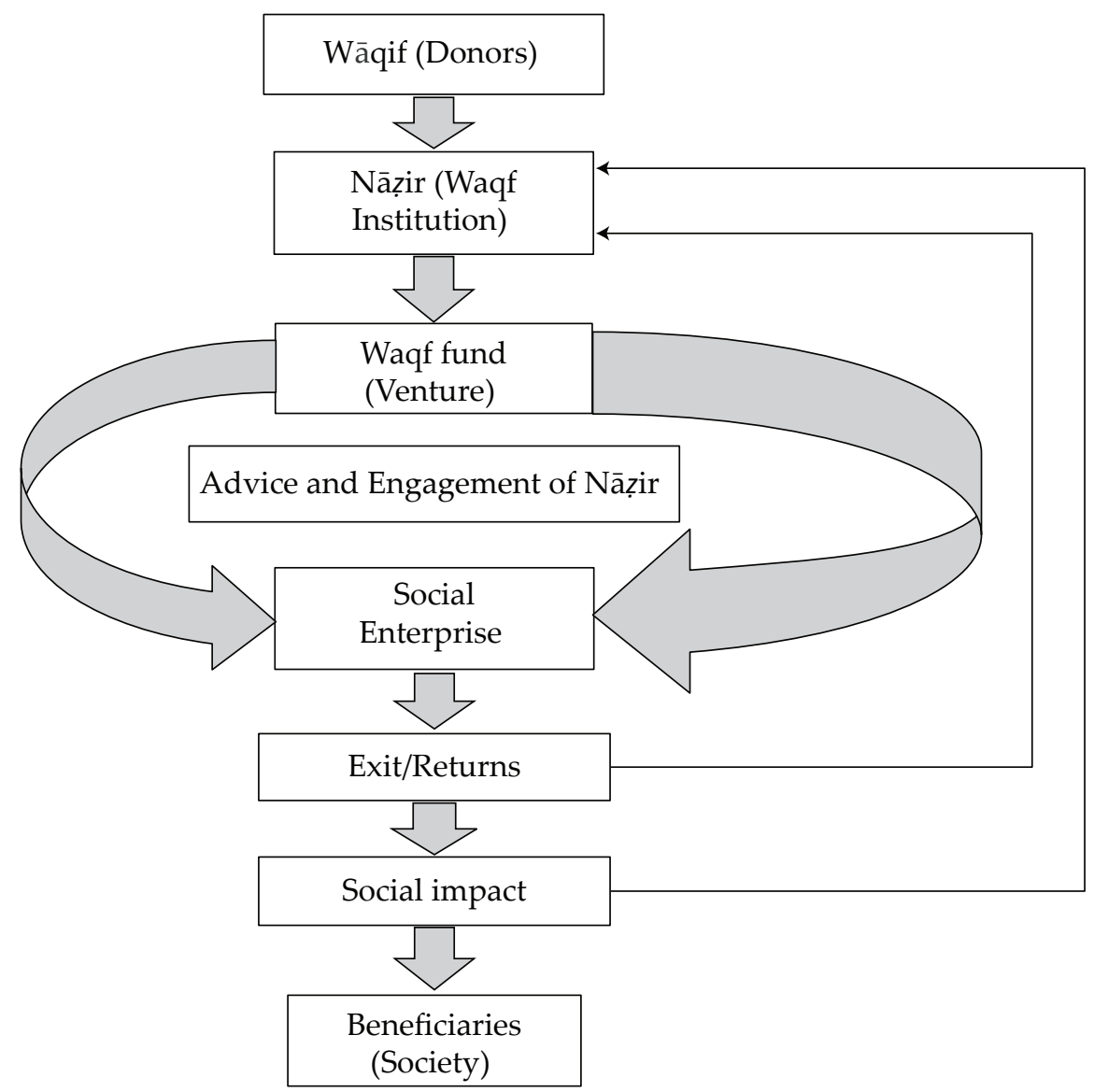

Source: Adapted from Alemany and Scarlata (2009 and 2010)

Figure 1. The Venture Philanthropy of Waqf Model

Figure 1 demonstrates the VPWM of waqf investment. Wāqif in the VPWM endows fund to the nāzir who will then invest in the high prospective social impact of social enterprises. The main goal of VPWM is to achieve and maximize social benefit rather than to concentrate on financial return maximization as accomplished in traditional venture capitals. ${ }^{15}$ It differs from the microfinance that is operated just like conventional venture capital that normally raises investment from cash-rich institutional investors, such as Grameen Bank in Bangladesh, and the VPWM accumulates capital from waqf contribution. In organizational structure, the microfinance model is principally the same as profit-maximizing business, but it is modified to be socially oriented as it targets the poor and the micro-enterprise.

15. Further explanation about Venture Philanthropy can be learnt from Scarlata and Alemany (2010). 
The model (VPWM) suggests that the social enterprise ${ }^{16}$ (social business entity) does not remain by just organizing its social entrepreneurial activities to become self-sustainable, but also to channel contributions to the society. In this regard, growth and sustainability of social enterprise can be achieved both through the provision of waqf fund as well as value added services which help support social enterprise on a strategic and managerial level. Additionally, the sustainable social enterprise entity is expected to establish another social enterprise by operating the same core of business or a different type of business (Zakaria et al., 2013).

Two types of returns can be obtained from the VPWM. First, if the funded 'social enterprise' has sound sustainability and has an ability to maximize its social impression, the return will be distributed to the society; and second, the self-sustainability of social enterprise is expected to create and empower the production of some financial returns (Scarlata and Alemany, 2010). If the social enterprise is a non-profit organization, revenues produced must be reinvested within the organization. On the contrary, if the social enterprise is a for-profit body, then any created returns can be redistributed to nāzirs and reinvested to another social enterprise through nāzirs. In this model, the nāzir has the authority to decide on the disposal of the waqf fund whether to reinvest or to distribute to the beneficiaries (society) as long as it complies with the sharì'ah.

In short, the venture philanthropy capital in the waqf fundraising model will engage a three-stage life cycle. The first phase is asset building (which may take different durations among waqf institutions which should take around five to ten years), during which time the VPWM will focus on fundraising and generating income. The second stage begins with the management and investment of the waqf funds. The third stage is utilizing revenue from investments to fund the intended objectives (Alias, 2012). Therefore, it is predicted that by executing the venture model in waqf fundraising would generate a new source of funding to achieve financial and social returns on the investments. This is for the reason that waqf would be supportively involved in business creation to the effect that the enterprise is completely owned by waqf institutions.

\subsubsection{Value-Based Capital Model of Waqf (VBCM)}

In this section, the difference between the value and the physical being of subject matter will be clarified. These dissimilarities are rooted from the different understanding of perpetuity and inalienability. At this point, the perpetuity of waqf is not understood as the perpetuity of its subject matter but its dedication to the value that is maintained and invested (Iman and Mohammad, 2014). It is proposed that the perpetuity of physical being of the object of waqf should be replaced by assigning a value to the dedication that can be safeguarded and invested. This is an effort to preserve the waqf as much as possible along with its maintenance and

16. UK DTI (2002) defines a social enterprise as "a business with primarily social objectives whose surpluses are principally reinvested for that (social) purpose in the business and the community". And, social entrepreneurship is defined as "entrepreneurial activity with social orientation and intent" (Johnson, 2000; Thompson, 2008). 
development. Additionally, effective management and maximum productivity are requirements to generate incomes and revenues that would be distributed to the beneficiaries.

Contemporary jurists proposed numerous definitions of waqf, but no essential amendment has thus far been proposed. Nevertheless, Kahf's (1998) definition of waqf deserves serious attention. Kahf (1998, p. 4) argues that the classical concept of waqf - "holding an asset and preventing its consumption for the purpose of repeatedly extracting its usufruct for the benefit of an objective representing righteousness and philanthropy" - needs to be reviewed and redefined. On the other hand, Kuran (2001) states that the static perpetuity and the rigidity of the waqf system proved "unsuitable for the relatively dynamic economy of the industrial age" (p. 843). As a response, Mohammad and Iman (2006) proposed an identification of waqf as "perpetual dedication of a valuable, the value of which is amortized subsequently, whereby the valuable or its proceeds is used or invested, and its revenue is then spent on the welfare of the named beneficiaries." (p. 34).

The meaning of perpetual dedication here is not the perpetuity of a physical object that is the subject matter of dedication. Perpetual dedication is materialised through amortization of the value of the principle object (Iman and Mohammad, 2014). From this understanding, as a result, the object of dedication can be perpetuity or otherwise, liquid and non-liquid assets, tangible and non-tangible assets. Moreover, according to Kahf (1998), the term valuable as a substitute of $m \bar{a} l$ is used to include human labor or time which may not be implied by māl as its usufruct (Iman and Mohammad, 2006). In short, perpetual dedication is not excluding temporal usage of an object. In other words, the definition agrees to temporality and alienability of the object. It stresses on the appraisal of the dedication even if it is for a shorter period.

The new interpretation of perpetuity that it should expand to new forms of waqf, such as chattels, cash, labor, usufruct, and others, as proposed by Kahf (2000), can be accepted even though for a shorter period (activation of temporary waqf). Furthermore, the International Council of Fiqh Academy (ICFA) declares the following fatwa:

"...the condition given by creator of an endowment with regard to the investment of the waqf is binding and does not nullify the requirement of waqf. It is also binding, even if he stipulates that the full investment returns are to be spent on specific areas. In this particular case, the investment returns cannot be used to enhance the principal amount, which is the waqf itself; if the creator of a family waqf did not stipulate any restrictions and did not stipulate that the waqf should be invested, then it is impermissible to invest part of the yield, except if such investments are approved by the beneficiaries. However, it is permissible to invest part of it for a prevailing public interest (mașlahah), subject to stipulated rules" (ICFA Resolution No. 140 (15/6), 2004).

The mentioned fatwa confirms the pliability of waqf as long as the wāqif needs to revoke it so that the waqf deed might not be burdened with rigidity. The purpose of this model is to focus on the difference between the value of waqf and its physical entity. The concept of value has several definitions. Values may be seen as absolutes (inaccessible to science), as inherent in objects (material or nonmaterial), as present within man, and as identical with his behavior (Adler, 1956, p. 272). 
In addition, anything capable of being appreciated (wished for) is a 'value'. The object has certain inherent qualities that may be desired by somebody (Adler, 1956). In this context, the value-based object of dedication that substitutes the permanency of the subject matter drives afar the restrictions of immoveable and moveable properties. According to Imām and Mohammad (2006), dedication could be implemented by amortisation of the value of things are capable of generating revenues, and things are not capable of producing returns which would be preserved differently.

In short, this means that under this model, the focus must be given to preserving the value of the dedication rather than the physical object of the subject matter. The VBCM of waqf, at least, will have a two-step life sequence. The first phase is asset building during which time the VBCM of waqf will focus on revenue-generating and non-revenue-generating waqf objects which should be valued in cash. The cash value should be considered the principal capital of waqf, henceforth referred to as value capital (VC). The second stage will start with the consideration of VC as perpetual and should be maintained all the time by the investments (Imām and Mohammad, 2006). All efforts should be prepared to protect the VC through its returns. In order to avoid loss, the large portfolio would be arranged to spread the risks. The following figures describe the model.

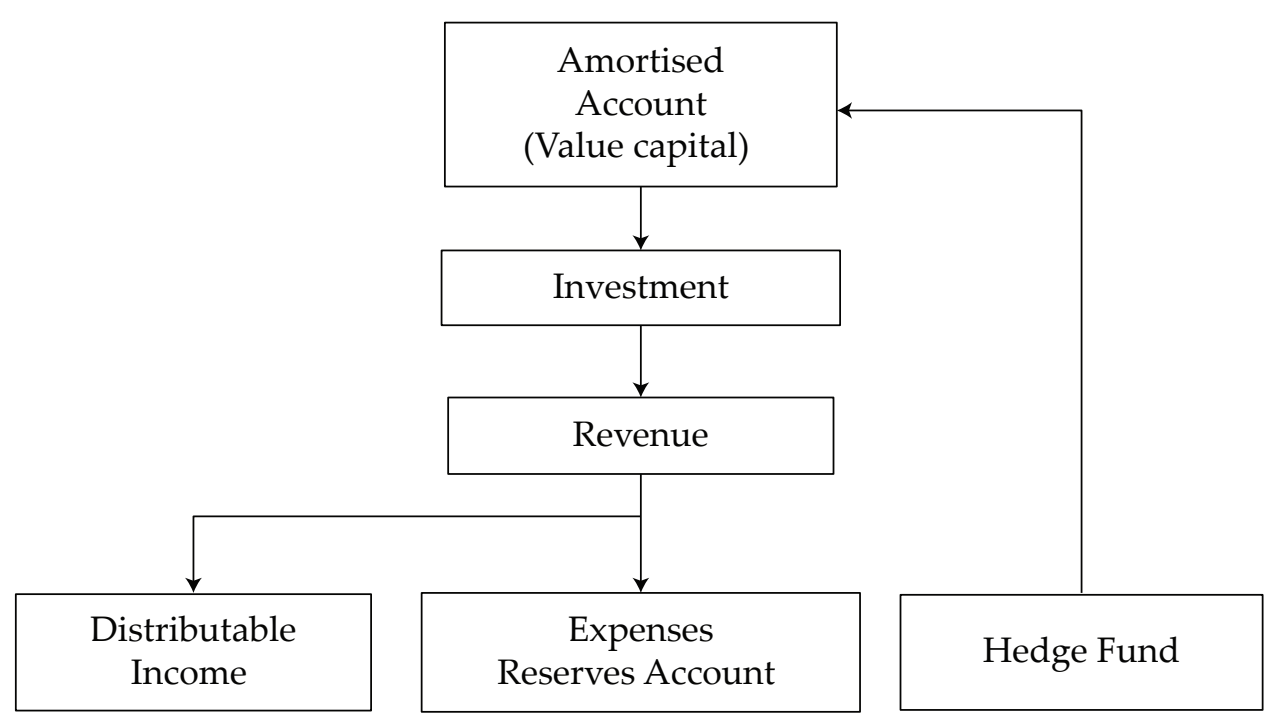

Source: Adopted from Iman and Mohammad (2006 and 2014).

Figure 2. A Value-Based Capital Model of Waqf

Based on the Figures 2 above, to assure the perpetuity of $\mathrm{VC}$, at this point, investment and revenue accounts should be matched to the VC account. All capitals in VC are required to be invested, and its revenues should be collected. These revenues should be separated into distributable income and expenses. The distributable income would be distributed to the beneficiaries of the waqf whereas the fund marked for expenses would be preserved in the reserve account. These 
funds could be placed in a larger fund (hedge fund). This is done to compensate losses in one of the principal capital accounts (Iman and Mohammad, 2006 and 2014). It is also projected that by applying the VBCM in waqf, fundraising would reduce the problem of non-liquidity of the waqf assets and to encourage the ummah to contribute to the further development of waqf institutions.

\subsubsection{Social Enterprise Waqf Fund Model (SEWF)}

In the following discussion, the investigation of the best possible enterprise models for waqf utilization will be described. As the objective of waqf is welfare, it can be argued that Social Enterprise Waqf Fund model (SEWF) that puts welfare as the ultimate priority is considered the most suitable model for sustainable (cash) waqf advancement. Moreover, waqf institution as one of the most vital non-profit organizations that exist in the Islamic heritage, certainly, has been applying many methods to ensure its continuity.

Accordingly, social enterprise seems a more applicable model for waqf as a nonprofit organization than venture business. It can be argued that social enterprise is a construct that bridges an important gap between business and benevolence. It applies profitable patterns to maximize social prosperity, rather than maximizing profits for shareholders. Since it is a value-driven business, "pairing such enterprise with waqf is seen to be more natural due to shared value" (Arshad and Haneef, 2015, p. 9).

The organizers of SEWF can be individuals or a group of administrators who are experts in social entrepreneurship activities. They have to invent new practices to produce additional and various sources of revenues. The following figure will describe the proposed model of SEWF that can be practised in the development of waqf. The structure of this model is highlighted below.

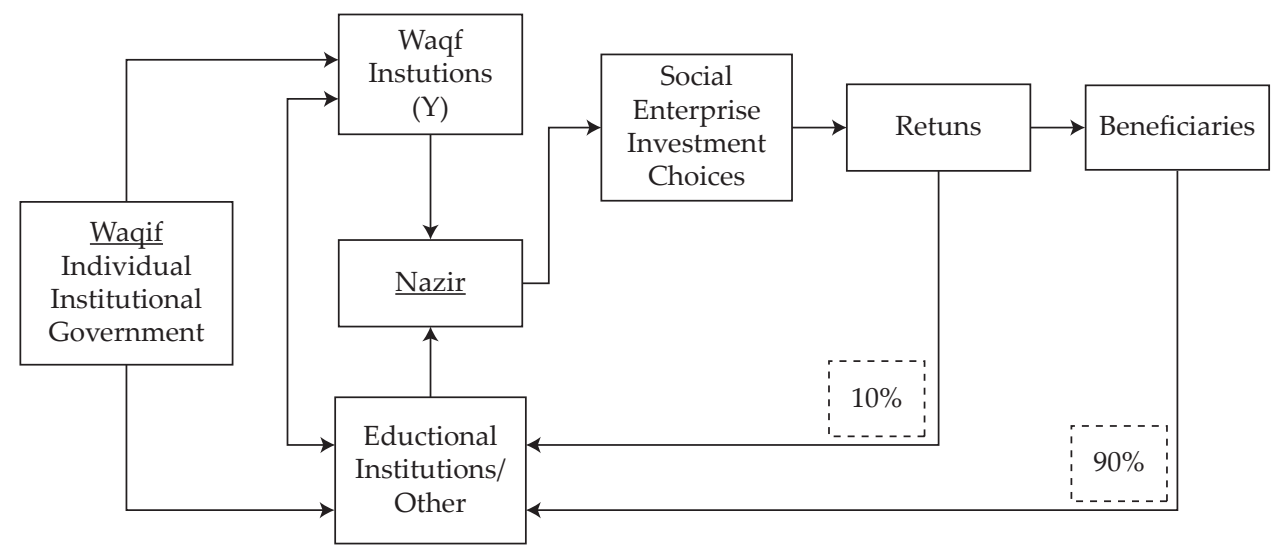

Source: Waqf Act of Indonesia (No. 41 of 2004), Mohsin (2009) and Alias (2010).

Figure 3. A Social Enterprise Waqf Fund Model 
The process flow of the SEWF model is as follows:

a. The wäqif (founder) will contribute to the social enterprise through waqf or educational institutions, and at the same time both institutions should give waqf funds/assets to the nāzir.

b. Nāzir should manage and invest the waqf fund. The nāzirs are expected to come from educational institutions or others who have the skills of social enterprise.

c. The investment returns will then be distributed to nāzir no more than $10 \%$ of return, and the $90 \%{ }^{16}$ of it should be circulated to beneficiaries including educational institutions and others.

This section has offered an overview of the SEWF model for the development of waqf fundraising and management. Hence, for the manager of a non-profit organization like waqf (nāzir), it needs a clear mission, careful placement, and continuous learning and teaching, management by objectives and self-control, responsibility and accountability for performance. In addition, a philanthropy venture capital, value-based capital, and social enterprise waqf fund models aim at structuring the waqf assets and funds in a modern and dynamic manner. However, this could only be done if the legal framework and the maqūșid sharī'ah are able to support the structure especially if it becomes a sensitive issue. Finally, SEWF as an innovation process in the waqf institutions that can be implemented by different waqf institutional contexts is based on value creation and operates by its rules and reasons. It is a model that seems well suited to support the sustainability of waqf institutions in Muslim society.

\subsection{The Framework of Management by Objectives (MBO) 4.5.1. The Basic Concept of Management by Objectives}

The primary concern of management is how to achieve the preferred outcomes efficiently. According to Maheswari (1969), emphasizing results has been the concern of the advancement of management methodologies and practices. The concept of MBO is proposed to reach that (objectives). Drucker (1954) views that $\mathrm{MBO}$ "is a process by which the members of an organization mutually establish its goals". The structure includes MBO ways of practicing the five basic management functions -planning, organizing, staffing, leading, and controlling. In current management literature, the terms of 'Management by Objective', 'Management by Results', 'Improving Business Performance' and 'Management by Drives', are used interchangeably to illustrate the management concept that emphasises result or goal-oriented action (Maheswari, 1969). This concept is commonly used in the non-governmental organization. In this regard, Kondrasuk (1981) asserts that $\mathrm{MBO}$ could be better for the private sector environment than the public-sector environment, even though no resilient evidence supports this view. McConkey (1965, p. 15) defines 'Management by Results' as:

16. The nisbah (percentage) of shared return is based on the hadith of Ibn Umar regarding the administrator of waqf who is allowed to take a portion of return to feed himself and his colleagues without excessive manner. 
"... an approach to management planning and evaluation in which specific targets for a year, or for some other length of time, are established for each manager, on the basis of the results which each must achieve if the overall objectives of the company are to be realised. At the end of this period, the actual results achieved are measured against the original goals -that is against the expected results, which each manager knows he is responsible for achieving."

Further definition can be learnt from Odiorne (1965, p. 55) who defines it as,

"...processes of management whereby the superior and subordinate managers of an organization jointly identify its common goals, define each individual's major areas of responsibility in terms of the results expected of him, and use these measures as guides for operating unit and assessing the contribution of each of its members."

According to Greenwood (1981), the main idea of the definition is that 'subordinates' take a pivotal part in arranging their objectives and not in simply getting objectives from 'superiors'. In this regard, there are four basic mechanisms of the MBO structure proposed by Drucker (1954): setting objectives, developing action plans, conducting periodic reviews, and appraising the annual performance. MBO mechanisms support managers to measure work against stated objectives. Furthermore, Odiorne (1965) asserts that MBO is 'a specific way of thinking about management'. Hence, it is expected that using the MBO structure in waqf institutions would be useful to scrutinize the essential role of nāzir in the management process of achieving organizational objectives. As shown in figure 4 below, $\mathrm{MBO}$ concept, in addition to completing one $\mathrm{MBO}$ cycle, is responsible for introducing the subsequent steps:

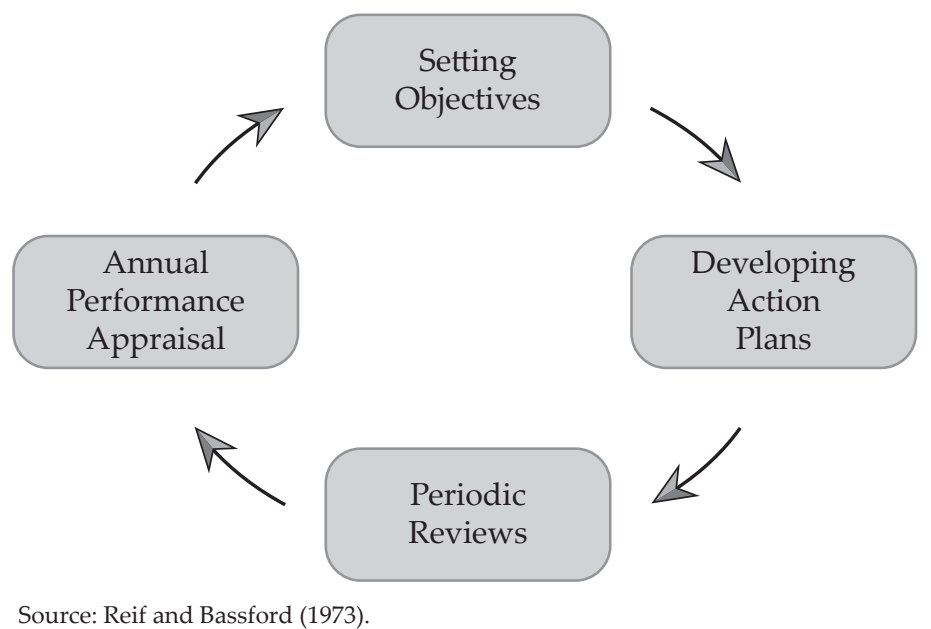

Figure 4. Management by Objectives Cycle

\subsubsection{Setting objectives}

According to Maheswari (1969), an objective is a description of wherever an organisation desires to direct. There are three fundamental foundations of an objective, "starting point, terminal point (the expected results), and the identified 
period of time in achieving the goal" (Maheswari, 1969, p. M3). Furthermore, Ordiorne (1965) classifies categories of performance goals: repetitive goals, emergency goals, innovative and creative goals, personal goals and development goals. In this regard, setting objectives, according to Reif and Bassford (1973, p. 26), is essentially a three-step process. The first step is identifying the areas of responsibility or activities that are considered important to the long-run success of the organisation. The second step is determining performance measurement for each area. The third step is setting objectives that serve as standards of which performance is measured. In other words, according to Maheswari (1969), this step defines the objectives of an organization to find its direction and determine its strategic goals.

\subsubsection{Developing action plans}

Planning is a vital step in finding out which procedure will be used, who will participate, and what data will be required to enact the plan (Worth, 2009). One may argue that the planning orientation is focused on arranging objectives and improving the plans, policies, and the programs to accomplish them. The first concern in developing action plans is dividing all of the tasks and activities into steps. The second concern is identifying any strategies. The third phase is distributing who is taking responsibility for each step. The fourth stage is determining the required resources. The fifth step is estimating the time required to perform each step. This step will ensure that each section or person knows what is expected during the specified period (Maheswari, 1969; Reif and Bassford, 1973).

\subsubsection{Conducting periodic reviews}

After setting an objective and developing action plans, the next step in the $\mathrm{MBO}$ mechanism is making a control system that will review the operation and designate which action being taken will result in the achievement of the stated objectives (Reif and Bassford, 1973). In this respect, the control system requires an understanding of the requirements for good performance. In addition, good performance is depicted as the personal capability to acquire goals and is weighed on the basis development being completed. This is followed by the feedback of information which is revealed in the principle that "motivation to accomplish goals inclines to develop as people are informed about substances affecting those goals" (Reif and Bassford, 1973, p. 28). In other words, awareness of the required objectives can make people in the organisation perform optimally.

\subsubsection{Appraising the annual performance}

The annual appraisal aims to review and evaluate what has been done in order to begin preparing for the coming year (Reif and Bassford, 1973). In the context of waqf, it is important to understand that waqf as a non-profit organisation does not base its strategy on money ${ }^{17}$ and make the center of its plans.

17. In other words, it can be said that waqf should not be profit-maximization oriented. 
However, a waqf institution starts with the performance of its mission. Its focus is on action. Therefore, the performance assessments may be held more than twice a year based on the organization's needs. In short, utilizing the MBO framework is expected to be able to capture how a waqf institution devotes a great deal to achieve the mission of the organization.

\section{V.CONCLUSION}

This paper presents the discussion about the concept of fundraising and management in waqf institutions. It is apparent that fundraising and management are the basis of waqf sustainability. For that reason, the importance of fundraising and management to revive awqāf institutions cannot be bargained. Fundraising here covers all energies to provide financial and non-financial resources in an attempt to integrate it into social entrepreneurial activities. There are several modes of fundraising for the development of waqf assets and funds such as VPWM, VBCM, and SEWF.

Moreover, in order to improve waqf institutions, there is a suggestion to adapt or adopt non-profit management techniques. Henceforth, there is a need to employ the Management by Objectives (MBO) framework in waqf institutions. It is expected that utilizing the MBO framework in waqf institutions would be useful to examine the central role (of the organization) in the management practice of achieving organizational objectives. In short, the reason for adapting non-profit fundraising and management mechanisms' framework is because it is closely pertinent to the waqf institution. However, so far, the existing studies on waqf fundraising and management are limited. This situation gives an opportunity to conduct a future study concerning fundraising and management within waqf institutions.

\section{REFERENCES}

Abbasi, M. Z. (2012). The Classical Islamic Law of Waqf: A Concise Introduction. Arab Law Quarterly, 26, pp. 121-153. http://doi.org/10.1525/sp.2007.54.1.23

Abu Zahrah, M. (2005). Muḥādarah fi al-Waqf. Cairo: Dar al-Fikr al-'Araby.

Al-Habshi, S. O. (1991). Waqf Management in Malaysia. In Ariff, M. (Ed.), The Islamic Voluntary Sector in Southeast Asia: Islam and the Economic Development of Southeast Asia. Singapore: Institute of Southeast Asian Studies.

Al-Hattab, A. (1995). Mawahib al-Jalīl fi Sharh Mukhtasar al-Khalīl. Beirut: Dar alKutub al-'Ilmiyah.

Al-Khatib, A.A. (1968). Al-Waqf wa al-Wașayā. Baghdad.

Ali, S. A. (1912). Mahommedan Law (Vol. 1). Thacker, Spink.

Al-Makassary, R. (2003). Relasi Filantropi Islam dan Keadilan Sosial di Indonesia. In Thaha, I. (ed.), Berderma untuk Semua: Wacana dan Praktik Filantropi Islam (pp. 141-153). Jakarta: Teraju.

Al-Marghinani, A. (1997). Al-Hidāyah Sharh Bidāyat al-Mubtadi. Beirut: Dar alKutub al-'Ilmiyyah.

Al-Nawawi, M. S. (1978). Minhaj al-Ṭālibīn. Beirut: Dar Al-Fikr.

Al-Nawawi, Y.S.D (1985). Rawdat al-Ṭālibìn. Beirut: al-Maktab al-Islami. 
Anderson, J. N. D. (1951). The Religious Element in Waqf Endowments. Journal of the RoyalCentral Asian Society, 38(4), pp. 292-299.

Andreasen, A. R. and Kotler, P.T. (2008). Strategic Marketing for Non-profit Organizations. Upper Saddle River, NJ: Prentice Hall.

Adler, F. (1956). The Value Concept in Sociology. American Journal of Sociology, 62 (3), pp. 272-279. http://www.jstor.org/stable/2772921

Ahmed, H. (2007). Waqf-Based Microfinance: Realizing The Social Role of Islamic Finance "Integrating Awqaf in the Islamic Financial Sector." Integrating Awqaf in the Islamic Financial Sector, 1-22.

Ahmed, H. (2011). Waqf as Sustainable Social Enterprise: Organizational Architecture and Prospects. In Fourth World Congress of Muslim Philanthropists, Dubai, March (pp. 23-24).

Arshad, M. N. M. and Haneef, M. A. M. (2013). Reositioning Issues of Waqf as a Third Sector Organisation Into the Mainstream Economy. Journal of Chemical Information and Modeling, 53(9), 1689-1699. http://doi.org/10.1017/ CBO9781107415324.004

Bakar, M. D. (1999). Amalan institusi wakaf di beberapa negara Islam: satu perbandingan (Waqf practices in Muslim countries: a comparison). IKIM Jurnal 7, 155-187.

Baer, G. (1982). Fellah and townsman in the Middle East: Studies in social history. Psychology Press.

Baskan, B. (2002, May). Waqf System as a Redistribution Mechanism in Ottoman Empire. In A paper presented at 17th Middle East History and Theory Conference.

Cacija, L. N. (2013). Fundraising in the Context of Non-profit Strategic Marketing: Toward a Conceptual Model. Journal of Contemporary Management Issues, 18(1), pp. 59-78.

Cattan, H. (1955). The law of waqf. Law in the Middle East, 1, pp. 203-223.

Crecelius, D. (1991). The Waqf of Muhammad Bey Abu al-Dhahab in Historical Perspective. International Journal of Middle East Studies, 23(1), 57-81.

Cizakca, M. (1998). Awqaf in History and Its Implications for Modern Islamic Economies. Islamic Economic Studies, 6(1), 43-70.

Cizakca, M. (2011). Islamic Capitalism and Finance: Origins, Evolution and the Future. Studies in Islamic finance, accounting and governance. http://doi. org/10.12816/0004984

Dallal, A. (2004). The Islamic Institution of Waqf: A Historical Overview. Islam and Social Policy, 13-43.

Drucker, P.F. (1954). The Practice of Management. New York: Harper.

Gaudiosi, M. M. (1988). The influence of the Islamic law of waqf on the development of the trust in England: The case of Merton College. University of Pennsylvania Law Review, 136(4), pp. 1231-1261.

Gil, M. (1998). The earliest waqf foundations. Journal of Near Eastern Studies, 57(2), pp. $125-140$.

Greenwood, R. C. (1981). Management by objectives: As developed by Peter Drucker, assisted by Harold Smiddy. Academy of Management Review, 6(2), pp. 225-230.

Hansmann, H. B. (1980). The Role of Nonprofit Enterprise. The Yale Law Journal 89 (5), pp. 835-901. http://www.jstor.org/stable/796089 
Harasani, H. (2015). Toward the Reform of Private Waqfs: A Comparative Study of Islamic Waqfs and English Trusts. Brill.

Hasan, S. (2010).Wakfs (Waqfs). In International Encyclopedia of Civil Society (pp.16301633). US: Springer.

Hasanah, U. (2003). Potret Filantropi Islam di Indonesia. In Thaha, I. (ed.), Berderma untuk Semua: Wacana dan Praktik Filantropi Islam (pp. 203-246). Jakarta: Teraju.

Hassan, A. and Shahid, M. M. A. (2010). Management and Development of the Awqāf Assets. In Seventh International Conference-The Tawhidi Epistemology: Zakat and Waqf Economy, Bangi (pp. 309-328).

Heyneman, S. P. (2004). Islam and Social Policy. Vanderbilt University Press.

Hoexter, M. (1998). Waqf Studies in the Twentieth Century: The State of the Art. Journal of the Economic and Social History of the Orient, 41, pp. 474-495.

Holloway, R. (2001). Towards Financial Self-Reliance. London: Aga Khan Foundation. Hull, C. E., and Lio, B. H. (2006). Innovation in Non-Profit and For-Profit

Organizations: Visionary, Strategic, and Financial Considerations. Journal of Change Management, 6(1), 53-65.

Ibrahim, M. S. M. and Yaakob, H. (2006). Waqf accounting in Malaysian State Islamic Religious Institutions: The case of Federal Territory SIRC. In IIUM International Accounting Conference III. Kuala Lumpur, 26-28 June, 2006.

Jalil, A. and Romli, A.M. (2010). Waqf Instrument for Contruction Contract: An Analysis of Structure. In Seventh International Conference -the Tawhidi Epistemology: Zakat and Waqf Economy. Bangi: Insitut Islam Hadhari, UKM.

Jones, L. (2005). The Encyclopedia of Religion. Detroit: Macmillan Reference USA.

Kahf, M. (1998). Fiqhi Issues in the Revival of Awqāf. Islamic Horizons Article retrieved from monzer. kahf.com/papers/.../revival_of_awqaf_-_islamic_horizon.pdf.

Kahf, M. (1999, October). Towards the Revival of Awqāf: A Few Fiqhi Issues to Reconsider. In Harvard Forum on Islamic Finance and Economics (Vol. 1).

Kahf, M. (1999). Financing the Development of" Awqāf" Property. American Journal of Islamic Social Sciences, 16(4), 39.

Kahf, M. (2000). Al Waqf al Islamy, Tatawwuruh, Idaratuh, Tanmiyatuh (Islamic Wqf, Its Growth, Management and Development). Damascus: Dar al Fikr.

Kuran, T. (2001). The Provision of Public Goods under Islamic Law: Origins, Impact, and Limitations of the Waqf System. http://www.jstor.org/stable/318. The Journal of Law and Society Association, 35(4), 841-898.

Layish, A. (1983). The Mālikī Family Waqf According to Wills and Waqfiyyāt. Bulletin of the School of Oriental and African Studies, 46(01), pp. 1-32.

Lindahl, W. E. and Conley, A. T. (2002). Literature Review: Philanthropic Fundraising. Nonprofit Management and Leadership, 13(1), pp.91-112.

Lorenzi, P., and Hilton, F. G. (2011). Optimizing Philanthrocapitalism. Society, 48(5), 397.

Mahamood, S. M. (2006). Waqf in Malaysia: Legal and Adminitrative Perspective. Kuala Lumpur: University Malaya Press.

Mahamood, S. M. and Ab Rahman, A. (2015). Financing Universities Through Waqf, Pious Endowment: Is It Possible? Humanomics, 31(4), pp. 430-453. http:// doi.org/10.1108/H-02-2015-0010

Maheshwari, B. L. (1969). Management by Objectives. Economic and Political Weekly, 4 (8), pp. M2-M3, M5-M7. 
McGoey, L. (2012). Philanthrocapitalism and Its Critics. Poetics, 40(2), 185-199.

Mahamood, S. M. (2007). The Establisment of Waqf Fund According to Shari'ah Perspective and Its Application in Malaysia. Jurnal Syari'ah 15 (2), pp.61-68.

McChesney, R.D. (1995). Charity and Philanthropy in Islam: Institutionalizing the Call to Do Good. Indianapolis, IN: Indiana University Centre for Philanthropy.

Mohammad, M. T. S., and Mar Iman, A. H. (2006). Obstacles of the Current Concept of Waqf to the Development of Waqf Properties and the Recommended Alternative. Malaysian Journal of Real Estate, 1(1), 27-38. Retrieved from http:// eprints.utm.my/501/

Mohammad, M. T. S. (2008). Sustaining the Means of Sustainability: The Need for Accepting Wakaf (Waqf) Assets in Malaysian Property Market.

Mohammad, M. T. S., and Mar Iman, A. H. (2014). Waqf Property: Concept, Management, Development, and Financing. Kuala Lumpur: Univesiti Teknologi Malaysia Press.

Mohsin, M. I. A. (2013). Financing Through Cash-waqf: A Revitalization to Finance Different Needs. International Journal of Islamic and Middle Eastern Finance and Management, 6(4), 304-321. http://doi.org/10.1108/17538391111144515

Mohd Zakaria, A. A., Abd. Samad, R. R., \& Shafii, Z. (2012). Venture Philanthropy -Waqf Practices and Its Implementation: Scenario in Malaysia. International Journal of Business, Economics and Law, 1, 108-115.

Odiorne, George. (1965). Management by Objectives: A System of Management Leadership. New York: Pitman.

Othman, M. Z. B. H. (1983). Origin of the Institution of Waqf. Hamdard Islamicus VI, 2, pp. 3-23.

Pepin, J. (2005). Venture capitalists and entrepreneurs become venture philanthropists. International Journal of Nonprofit $\mathcal{E}$ Voluntary Sector Marketing, 10(3), 165-173. http://doi.org/10.1002/nvsm.10

Powers, D. S. (1999). The Islamic Family Endowment (Waqf). Vand. J. Transnat' L., 32, 1167.

Prihatna, A. A. (2005). Filantropi dan Keadilan Sosial. In Bamualim, C.S. and Abubakar, I (eds.), Revitalisasi Filantropi Islam: Studi Kasus Lembaga Zakat dan Wakaf di Indonesia (pp. 3-7). Jakarta: Pusat Bahasa dan Budaya, Universitas Islam Negeri Jakarta.

Raissouni, A. (2001). Islamic 'Waqf Endowment': Scope and implications (A. Benhallam, Trans.). Rabat: Islamic Educational, Scientific, and Cultural Organisation, ISESCO, www edition.

Reif, W. E. and Bassford, G. (1973). What MBO Really Is: Results Require a Complete Program. Business Horizons, 16(3), pp. 23-30.

Sabri, 'I.S. (2008). Al-Waqf al-Islamy Bayna al-Nadhzariyahwa at-Tatbiq. Amman: Dar al-Nafais.

Shamsiah, A.K. (2010). Contemporary Sharīah Structure for the Development and Management of Waqf Assest in Singapore. Doctoral Dissertation. Durham: Durham University.

Sait, S., and Lim, H. (2006). Land, Law and Islam. Property and Human Rights in the Muslim. 
Sait, S., \& Lim, H. (2006). Land, Law and Islam: Property and Human Rights in the Muslim World (Vol. 1). Zed Books.

Sarakhsī, M. A. (1993). Al-Mabsūt (Vol. 12). Beirut: Dar al-Ma'rifah.

Scarlata, M., and Alemany, L. (2010). Deal Structuring in Philanthropic Venture Capital Investments: Financing Instrument, Valuation and Covenants. Journal of Business Ethics. http://doi.org/10.1007/s10551-011-0851-8

Siraj, S. S. A. (2012). An Empirical Investigation into the Accounting, Accountability and Effectiveness of Waqf Management in the State Islamic Religious Councils (SIRCs) In Malaysia, (September), pp. 1-414. Retrieved from http://orca.cf.ac. $\mathrm{uk} / 46875 /$

Siswantoro, Dodik and Dewi, M. K. (2007). The Effectiveness of Waqf Fund Raising Through Mutual Fund in Indonesia. Singapore International Waqf Conference 2007, 243-268.

Stibbard, P. Qc, D. R., and Bromley, B. (2012). Understanding the Waqf in the World of the Trust. Trusts $\mathcal{E}$ Trustees. http://doi.org/10.1093/tandt/tts087

Sulaiman, M., Adnan, M. A., Nor, M. M., and Suad, P. N. (2009). Trust Me! A Case Study of the International Islamic University Malaysia's Waqf Fund. Review of Islamic Economics, 13(1), pp. 69-88.

Tahir, I. and Brimble, M. (2011). Islamic Investment Behaviour. International Journal of Islamic and Middle Eastern Finance and Management, 4(2), pp. 116-130.

Tunku Alina, A. (2012). Venture Capital Strategies in Waqf Fund Investment and Spending. ISRA International Journal of Islamic Finance, 4(1), 99-126.

Warwick, M. (1999). The Five Strategies for Fundraising Success: A Mission-Based Guide to Achieving Your Goals. San Francisco: Jossey Bass.

Worth, M. J. (1993). Educational Fund Raising: Principles and Practice. American Council on Education Series on Higher Education. Washington, DC: Case Publications.

Worth, M. J. (2009). Nonprofit Management: Principles and Practice. Singapore: Sage Publications.

Yunus, M., Moingeon, B., and Lehmann-Ortega, L. (2010). Building Social Business Models: Lessons from the Grameen Experience. Long range planning, 43(2), 308325.

Zakaria, A. A. M., Samad, R. R. A., \& Shafii, Z. (2013). Venture Philanthropy Waqf Model: A Conceptual Study. Jurnal Pengurusan, 38, 119-125.

Zarqa, M. A. (1994). Financing and Investment in Awqāf Projects: A Non-technical Introduction. Islamic Economic Studies, 1(2), pp.55-62. 
This page is intentionally left blank 